\title{
Steinbeck as Anti-Fascist
}

\section{Charles Williams}

In 1938 John Steinbeck wrote a statement in support of Republican Spain as part of the Writers Take Sides volume published by the League of American Writers. Joining an array of prominent authors who took an anti-fascist position in the collection of 418 "letters about the war in Spain" (only one contributor supported Franco), Steinbeck's brief statement was notable for its emphasis on what he described as a parallel form of fascism in the United States. "Just returned from a little tour in the agricultural fields of California," his letter begins. "We have our own fascist groups out here. They haven't bombed open towns yet but in Salinas last year tear gas was thrown in a Union Hall and through the windows of workingmen's houses. That's rather close, isn't it?"।

Steinbeck was referring to the repression of farm workers by the largescale corporate farm interests that dominated California agriculture. To equate this situation with fascism might seem a mere rhetorical flourish. For Steinbeck, however, it was a considered political conclusion. By this time he had made extensive visits to the squatters' camps in California's Central Valley, writing about the plight of migrant farm workers in a series of articles published in 1936 by the San Francisco News and reprinted (with a new epilogue) in 1938 as a pamphlet entitled Their Blood Is Strong. ${ }^{2}$ The heart of the problem, Steinbeck argued, was the intertwined economic and political power of the "speculative farmers" (corporate farms) organized as Associated Farmers, Inc., and tightly linked to banks, newspaper publishers, and politicians. This alliance-what 
Steinbeck elsewhere labeled a "fascist group of utilities and banks and huge growers"- employed a variety of coercive means to secure cheap labor, including the physical violence used to defeat workers' organizing efforts. More broadly, Steinbeck worried that the state as a whole was losing its democratic character under the sway of agribusiness: "If ... as has been stated by a large grower, our agriculture requires the creation and maintenance at any cost of a peon class, then it is submitted that California agriculture is economically unsound under a democracy. ... Fascistic methods are more numerous, more powerfully applied, and more openly practiced in California than any other place in the United States." Such views, of course, would also be forcefully expressed by Steinbeck in The Grapes of Wrath, largely written between May and October of 1938.

In light of this sustained attention to the threat of fascism, the following analysis explores the nature of Steinbeck's anti-fascist politics as a basis for understanding his overall political views, including in particular the scope and boundaries of his ties to the left between the late 1930s and World War II. Scholars have in fact devoted much attention to exploring Steinbeck's radicalism (or lack thereof) in this period, with perspectives ranging from emphasizing his liberalism and New Deal affinities, to asserting a growing radicalism that led to The Grapes of Wrath, to aligning his work with the genre of proletarian fiction and stressing his engagement with the Communist Party and the Popular Front. ${ }^{4}$ Yet the significance of anti-fascism as a starting point for analyzing Steinbeck's politics during the 1930s has received little sustained attention. Even those works devoted to considering Steinbeck's wartime efforts against fascism have not emphasized the connection between this activity and his earlier response to what he saw as domestic fascism in California agribusiness in the 1930s. One scholar goes so far as to misleadingly assert that Steinbeck did not get involved in "antifascist committees and efforts in the thirties, because he was absorbed in the problems of the economy and his own writings about them." Against this claim, an analysis of Steinbeck's response to fascism can provide us with a central thread that ties together his major cultural and political activities across the New Deal and wartime eras.

Disregard for the depth and consistency of Steinbeck's concern with fascism is particularly significant since anti-fascism has in recent years received renewed attention as a central aspect of left-aligned cultural production in the Popular Front milieu of the 1930s and early 1940s. In his prominent analysis of the Popular Front's cultural significance, for example, Michael Denning defines the Popular Front (in its American expression) as a "radical social-democratic movement forged around anti-fascism, anti-lynching, and the industrial unionism of the CIO." An analysis of Steinbeck through the lens of anti-fascism can accordingly provide a further significant indication of how such politics helped to constitute a broad left alliance in this period. At the same time, however, tracing the ongoing importance of fascism to Steinbeck's political anxieties and commitments does not amount to identifying Steinbeck with the perspectives 
of the Communist Party-aligned left that played a leading role in the American radicalism of the 1930s. Instead, Steinbeck's confrontation with fascism, including his emphasis on the danger of domestic fascism in America, was sufficiently ambiguous that we can still understand his politics in liberal-progressive terms, even as his positions and political life overlapped with the Communist Party in the Popular Front context.

To explore this claim and its political ramifications, we need to begin with the recognition that Steinbeck's analysis of fascism had its origins in his more general account of the destructive possibilities inherent in mass politics and group behavior. From that starting point, I will argue, we might see Steinbeck as upholding the integrity (in his view) of liberal individualism and American democratic traditions against mass repression, including fascism. In this sense, Steinbeck's politics were consistent with the evolving New Deal liberalism that maintained an emphasis on individual liberty while embracing the related need for state action to regulate or mitigate the consequences of business power and preserve the democratic capitalist order. ${ }^{7}$ On the other hand, to the extent a proto-fascism driven by business interests was perceived as having already eroded the old American order in contexts such as California's agricultural economy, Steinbeck's agrarian populism and participation in several left-wing cultural organizations connected him to radical efforts to break the power of economic elites. Internationally, Steinbeck's response to fascism in Germany and Spain can be understood in similar terms, with much of the analysis, including his treatment of fascism in The Moon Is Down, conveying a defense of and faith in liberal man against the repressive group or collective impulses he associated with Nazism. Yet Steinbeck's own activities in relation to this growing danger nonetheless brought him into contact with Popular Front anti-fascist initiatives led by Communists and their close allies, even as he perceived similar repressive dangers in the mass politics of Communism.

In engaging with the Communist left while maintaining his own distinctive commitments to American liberalism, Steinbeck's response to fascism highlights the breadth of the Popular Front as a political formation. In this regard, my analysis accords with Denning's interpretation of the Popular Front as a broad alliance that extended far beyond the Communist Party to combine multiple political and cultural strands and reshape American political culture. ${ }^{8}$ At the same time, Steinbeck's anti-fascism carried with it a larger political perspective that in some respects pointed the way to the demonizing anti-communism of the postwar period (even if Steinbeck himself did not participate in that domestic anti-communism). As Michael Rogin notes, Denning's broadly inclusive analysis of the Popular Front serves to obscure this kind of tension or conflict within the left-liberal alliance, highlighting solidarity over political controversy and in important respects purging internal politics from the cultural front altogether. ${ }^{9}$ A close consideration of Steinbeck's anti-fascism can bridge the divide between these two perspectives, exploring both the leftward shift of liberal political culture in the 1930s and the boundaries of that liberalism 
with regard to a Communist-linked political radicalism understood in part as a potential threat to the American liberal tradition. In what follows, I therefore begin by tracing the origins of Steinbeck's views on fascism and his willingness to apply this analysis to farm interests in California. I then turn to considering how Steinbeck developed an equivalent understanding of fascism in Europe. Having established the consistency and breadth of his analysis of fascism in the period from the early 1930s into the war, I then conclude by exploring how this perspective led Steinbeck to an active involvement in the Popular Front while at the same time generating a set of related fears about left-wing politics that anticipated the logic of postwar anti-communism.

\section{The Mass Politics of Fascism}

Steinbeck's understanding of fascism was rooted in an analysis of mass politics that he developed in the early 1930s. Writing to his college roommate, Carlton Sheffield, in an important letter that outlined what subsequently became his "Argument of Phalanx," Steinbeck asserted that under the right conditions, individuals could be transformed into a group entity (the phalanx) that acts as a single being, and that "when acting as a group, men do not partake of their ordinary natures at all." The emergence of the phalanx explains such events as mass migrations and the upheavals of "Genghis Khan and Attila and the Goths" and, with regard to fascism, constitutes "the impulse which has suddenly made Germany overlook the natures of its individuals and become what it has." As Steinbeck elaborates on the nature of such group behavior: "the fascinating thing to me is the way the group has a soul, a drive, an intent, an end, a method, a reaction and a set of tropisms which in no way resembles the same things possessed by the men who make up the group." ${ }^{\prime 10}$ In some respects, Steinbeck aimed merely to describe this dynamic, developing a theory that in his view synthesized (and verified) insights drawn from biological science, Jungian theories of the unconscious, anthropology, and a host of other fields. Yet when applied to political developments such as the rise of fascism, Steinbeck's analysis of this mass phenomenon clearly indicated its dangerous implications for humanity. ${ }^{11}$

Among the impulses of "group-man," he argued, were "emotions of which the unit [individual] man is incapable. Emotions of war, of migration, of hatred, of fear." In historical terms, Steinbeck continued, "we can find no man unit reason for the sudden invasion of Europe by a race of Hun shepherds, who were transformed overnight into a destroying force, a true phalanx, and in another generation had become shepherds again." When considering the repressive nature of mob action, it was therefore crucial to recognize just how different a mass of men behaved in comparison to the same individuals acting alone. "You have heard about the trickiness of the MOB," he wrote to George Albee, "[the] mob is simply a phalanx, but if you try to judge a mob nature by the nature of its men units, you will fail as surely as if you tried to understand a man by study- 
ing one of his cells." ${ }^{12}$ Instead, in mobs, men descended to a kind of subhuman behavior, as Steinbeck had earlier noted to Sheffield: "as individual humans we are far superior in our functions to anything the world has born-in our groups we are not only not superior but in fact are remarkably like those most perfect groups, the ants and bees." ${ }^{13}$ In turn, the leaders of a mob or phalanx- specifically including Hitler - were not its cause, but merely gave direction to a more fundamental impulse: "Hitler did not create the present phalanx in Germany, he merely interprets it." 14

Fascism thus involved a kind of mass mobilization rooted in emotional and destructive impulses that overwhelmed individual identity. At the same time, Steinbeck saw organized business interests mobilizing the mob to serve business goals. The phalanx perspective therefore associated fascism with earlier forms of mob upheaval but also recognized specifically modern economic pressures that encouraged destructive mass behavior. As Jackson Benson notes, this emerging view of the world was clearly connected to the moment of the early 1930s, "when mass movements were much discussed" and "capitalism as rugged individualism was seen by many as having failed." For Steinbeck, the mass character of the upheavals generated by this crisis marked a severe danger. As Benson points out, "A fairly accurate way of describing Steinbeck, perhaps even more accurately than a New Deal Democrat with middle-class values, is as an independent who valued individuality." Accordingly, Steinbeck's " anticommunism' came largely out of an awareness that it squashed individuality." 15 But if German fascism and Soviet communism were central contemporary examples that Steinbeck could reference as confirmation of his emerging phalanx theory, his first sustained engagement with what he regarded as fascism was domestic, involving the agricultural economy in California. In this respect, Steinbeck joined Carey McWilliams and other California liberals and radicals of the time in seeing fascism as a phenomenon that linked American and international politics. As Daniel Geary argues, such a perspective challenges the view that "left-wing antifascism as a movement ... directed its attention solely to international developments, such as the Spanish Civil War, at the expense of domestic concerns." 16

In terms of Steinbeck's published work, the first extended analysis of farm fascism and its devastating impact on farm workers appears in his 1936 novel In Dubious Battle. Here Steinbeck clearly identifies corporate farming as the cause of the workers' misery and as a kind of proto-fascism that fundamentally threatens American democracy. Yet the portrayal of workers in the novel also gives an early indication of Steinbeck's concerns about the similar dangers of repressive collective action on the left.

In Dubious Battle pits striking apple pickers and Communist organizers against a unified Growers' Association in the fictional Torgas Valley. The novel focuses on the manipulative efforts of the Communists in relation to the migrant workers' transformation into a phalanx, but the context for these developments is provided by the power and brutality of the business interests. Early on, the 
lead organizer Mac anticipates the arc of the struggle (and key elements of the novel) as he describes the likely results of a strike for higher wages to his apprentice, Jim. "Suppose the owners do meet the demands?" asks Jim. "I don't think they will," Mac responds, explaining that "there's the bulk of power in the hands of a few men. That always makes 'em cocky." Instead, Mac foresees an escalating conflict driven by the repressive actions of the owners:

Now we start our strike, and Torgas County gets itself an ordinance that makes congregation unlawful. Now what happens? We congregate the men. A bunch of sheriff's men try to push them around, and that starts a fight. There's nothing like a fight to cement the men together. Well, then the owners start a vigilantes committee, bunch of fool shoe clerks, or my friends the American Legion boys trying to pretend they aren't middle-aged. . . . Well, the vigilantes start shooting. If they knock over some of the tramps we have a public funeral; and after that, we get some real action. Maybe they have to call out the troops. ... The troops win all right! But every time a guardsman jabs a fruit tramp with a bayonet a thousand men all over the country come on our side. Christ Almighty! If we can only get the troops called out. ${ }^{17}$

After a confrontation with the police and scab workers, Mac again explains the depth of the problem facing the workers: "They got this valley organized. God, how they've got it organized. It's not so hard to do when a few men control everything, land, courts, banks. They can cut off loans, and they can railroad a man to jail, and they can always bribe plenty." 18

Concentrated economic power leads to a rigged and repressive political order that traps the farm workers in exploitative jobs and triggers their own potentially violent response. The political economy outlined by Steinbeck thereby produces destructive mob behavior in multiple respects. As the owners mobilize against the farm workers, they turn to vigilante violence alongside their other forms of power. And as workers react, they too become a brutal phalanx driven by subrational impulses. When vigilantes kill one of Mac's comrades during the showdown with the scabs, for example, the strikers become a single entity intent on violent retribution: "Can't you see, mister?" says a strike leader (London) to the sheriff, "If you guys don't get the hell out of here, can't you see your goin' get killed?" Steinbeck then emphasizes the animal nature of the worker-phalanx: "From the mob there came a rustle of released breath. The sheriff said, 'I'm not through with you,' but he backed away, and his deputies backed away. The mob growled, so softly that it sounded like a moan." 19 The possibility that workers might consciously organize to challenge farm interests is in this way displaced by a view of the struggle as an endless destructive cycle 
driven by the deeper logic of the phalanx, what Steinbeck described as a matter of "self-hate" and "a terrible order, a frightful kind of movement." 20

This phalanx analysis may have an abstract quality, but it would be wrong to see it as apolitical, or as merely using the labor struggle for symbolic purposes that were unrelated to Steinbeck's subsequent political views on events in the 1930s. ${ }^{21}$ Accordingly, Their Blood Is Strong presents this same perspective on California agriculture, making explicit the connection to fascism. Corporate farms seek to regulate and exploit migrant workers, and the end result in places such as the Imperial Valley is "a system of terrorism that would be unusual in the Fascist nations of the world." As with the analysis in In Dubious Battle, business success hinges on strong organization: "The large farms in California," Steinbeck writes, "are organized as closely and are as centrally directed in their labor policy as are the industries and shipping, the banking and public utilities." Although small farmers may not share the same attitudes toward labor, "it is rare for a small farmer to be able to plant and mature his crops without loans from banks and finance companies." Moreover, because large farm interests also dominate the newspapers and radio, "they are able not only to represent themselves as the whole body of California farmers, but are actually able to impose their policies on a great number of small farms." 22

The resulting labor repression is severe: "The attitude of the employer on the large ranch is one of hatred and suspicion; his method is the threat of the deputies' guns. . . . The workers are herded about like animals." Any sign of worker organizing leads to immediate blacklisting and the threat of violence, since "the large ranch owners know that if organization is ever effected there will be the expense of toilets, showers, decent living conditions, and a raise in wages." In response, the workers are pushed to the point of upheaval in a cyclical process that mirrors the account in In Dubious Battle: "The dignity of the men is attacked. No trust is accorded them. They are surrounded as though it were suspected that they would break into revolt at any moment. It would seem that a surer method of forcing them to revolt could not be devised." Ultimately, the nature of this system threatens the core values of the American social order. "If the terrorism and reduction of human rights, the floggings, murder by deputies, kidnappings, and refusal of trial by jury are necessary to our economic security," Steinbeck writes, "it is further submitted that California democracy is rapidly dwindling away." Denied the opportunity to be "socially responsible," the workers will similarly come to threaten the social order: "To attempt to force them into a peonage of starvation and intimidated despair will be unsuccessful. They can be citizens of the highest type, or they can be an army driven by suffering and hatred to take what they need." ${ }^{23}$

In this sense of impending explosion, it is again clear that the political economy of farm fascism intersects with what Steinbeck sees as a profound group transformation understood in terms of the phalanx. Yet while Steinbeck continually explores fascism at the level of both masses and elites, there is some possible ambiguity about how capitalist economic motivations interact 
with the mass politics of the phalanx. In other words, if proto-fascist politics in California derive from a specific class interest consciously mobilized to control labor, how does this fit with the idea of fascism as the irrational expression of a group psychology or biological dynamic that triggers mass upheaval? One way of reconciling these different levels of analysis is to see business or political elites and socioeconomic conditions as triggering a deeper impulse among the masses, to which organized political or class interests then give direction. Steinbeck implies this kind of perspective when he describes Hitler as "interpreting" the phalanx in Germany, and he develops a similar analysis in his narrative contribution to Sea of Cortez, published in 1941. As he observes, "Leaders and would-be leaders are so afraid that the idea 'communism' or the idea 'fascism' may lead to revolt, when actually they are ineffective without the black earth of discontent to grow in." While this remains vague, there is the suggestion here that specific material conditions - such as those established by business interests aiming to repress labor - create a context in which the politics of fascism (and communism) might take hold and produce the phalanx. Steinbeck accordingly continues, "the idea is dangerous only when planted in unease and disquietude. But being so planted, growing in such earth, it ceases to be idea and becomes emotion and then religion. ${ }^{24}$ Along these lines, corporate farming is laying the basis for mass upheaval both in terms of mob repression of the farm workers and the farm workers' own reactions, and all of this adds up to a transformative crisis for the state and by implication for the American way of life.

This analysis also linked Steinbeck to international arguments about the nature of fascism that were then circulating domestically. US Trotskyists read and debated the work of French radical Daniel Guerin, whose Marxist analysis of fascism was promoted in the United States by the Trotskyist Socialist Workers Party. Guerin's influential Fascism and Big Business was excerpted in translation in 1938 in the New International, a year before the full book was published in the United States. Though writing about Germany and Italy, Guerin's analysis had significant overlap with Steinbeck's views. Guerin emphasized the centrality of big business backing for German and Italian fascism, but also noted the crucial importance of mobilizing mass support for fascism through "mysticism" and "social demagogy." Guerin highlighted Hitler's view that the masses "can most easily be taken over in the domain of the emotions," so that "the force that set in motion the most violent revolutions ... [was] a driving fanaticism and a real hysteria which madly excited them." He went on to conclude that fascism "presents itself, above all, and even before trying to define itself, as a religion." 25 Steinbeck's synthesis of political economy and mass behavior was in this respect in line with an important strand of socialist analysis, although his group-man perspective on the underlying causes of fascism did not always give clear primacy to class interests in the manner of the Marxist tradition.

That said, Steinbeck's views on the ultimate consequences of fascism did incorporate a kind of class analysis consistent with a perspective put forward by 
dissenting anti-Stalinist radicals, including such a well-known figure as Dwight Macdonald. In 1941 Macdonald, at the time still connected to the Trotskyist left, rejected what he saw as the standard Marxist view by arguing that fascism displaced, rather than upheld, capitalist class interests. Macdonald was explicitly breaking with accounts such as Guerin's that he had previously endorsed when he wrote the introduction to the 1939 American edition of Fascism and Big Business. In place of capitalism, Macdonald argued, German fascism established a new social order dominated by a bureaucratic collectivist elite that had its communist equivalent in Stalinist Russia. ${ }^{26}$ Steinbeck briefly suggested a similar conclusion in Sea of Cortez, observing that fascism would wipe out the very business interests that embraced it: "The strike-raddled businessman may lean toward strikeless Fascism, forgetting that it also eliminates him." Notably, Steinbeck also claimed that the same danger awaited radicals who confronted these business interests: "The rebel may yearn violently for the freedom from capitalist domination expected in a workers' state, and ignore the fact that such a state is free from rebels." In this, Steinbeck, like Macdonald and others, was anticipating the analysis of left and right variants of totalitarianism that would define postwar liberalism. ${ }^{27}$ Such a critique could, of course, also be a radical one, opposing Soviet repression and the Stalinized Communist Parties from a left position that remained committed to working-class revolution, as did the Trotskyists and others in this period..$^{28}$ For Steinbeck, however, the possibility of repressive outcomes in the mass politics of both the left and the right was more absolute, rooted as it was in his general theory of irrational group man that applied to workers' struggles as much as to other forms of collective action. Yet, as we will see in the context of the Popular Front, Steinbeck still found it possible to work alongside and identify with the Communists in response to the threat of fascism.

The ominous possibility of repressive mass politics was further expressed in The Grapes of Wrath, even as Steinbeck also celebrated the resources of democratic resistance embodied in the so-called Okies. An early interstitial chapter sets the Joads' plight into context by describing how the bank-monster driven by profit is compelled to take the land from the family farmers in Oklahoma. ${ }^{29}$ Turned into migrants, the deprivations of the road and then the corporate farms transform the Okie workers into a potentially explosive phalanx, resembling insects in the manner of Steinbeck's earlier views on the subhuman qualities of group man: "suddenly the machines pushed them out and they swarmed the highways. The movement changed them; the highways, the camps along the road, the fear of hunger and the hunger itself changed them. ... They were migrants. And the hostility changed them, welded them, united them. ${ }^{30}$ From the other side, "the companies, the banks worked at their own doom and they did not know it. ... The great companies did not know that the line between hunger and anger is a thin line. And money that might have gone to wages went for gas and guns, for agents and spies, for blacklists, for drilling. On the highways the 
people moved like ants and searched for work, for food. And the anger began to ferment." ${ }^{31}$

Importantly for present purposes, Steinbeck also devotes more attention to the mob mobilized by proto-fascist business interests than he does in In Dubious Battle: "In the West there was panic when the migrants multiplied on the highways. Men of property were terrified for their property. . . . And the men of the towns and the soft suburban country gathered to defend themselves; and they reassured themselves that they were good and the invaders bad, as a man must do before he fights." Here Steinbeck highlights the rationalizations used to justify the mob instinct that in his view derives from more basic impulses. The interaction of elite interests and the local mobs is then depicted in clear phalanx terms: "The local people whipped themselves into a mold of cruelty. Then they formed units, squads, and armed them - armed them with clubs, with gas, with guns. We own the country. We can't let these Okies get out of hand. And the men who were armed did not own the land, but they thought they did." ${ }^{\prime 32}$

At the heart of Steinbeck's domestic political analysis in the late 1930s was his conviction that the extreme corporate farming in California amounted to proto-fascist capitalism and thus posed a threat to American traditions. His personal response to this perceived crisis reflected both his support for the farm workers and a fear of repressive mass behavior. At one level, Steinbeck articulated a solution that strongly resembled the New Deal vision of combining government action and pluralist interest group mobilization to counterbalance corporate power. This would preempt the threat of social instability and in turn secure individual freedoms in the context of a revitalized liberal democratic order. ${ }^{33}$ As Steinbeck argued in Their Blood Is Strong, resisting farm fascism required the "organization of middle-class people, workers, teachers, craftsmen, and liberals to fight this encroaching social philosophy." ${ }^{\prime 34}$ Yet in his willingness to openly label business power as a form of domestic fascism and to question whether California was in the process of losing its democratic character, Steinbeck was clearly raising more radical concerns about American politics. It was in this context that he became involved with the Popular Front.

A domestic framework is not sufficient for understanding Steinbeck's views of California fascism, however. His public statements and fiction provide an international context for the scope and consistency of his anti-fascism. As noted in the introduction, Steinbeck's contribution to the League of American Writers' pamphlet Writers Take Sides (1938) connected European fascism with California agribusiness as a significant part of his statement on the Spanish Civil War. The League of American Writers was a Popular Front organization founded by the Communist Party in 1935 as a forum where prominent writers could collaborate politically with Party cultural figures. As the Party increasingly adopted a Popular Front framework after 1935, the League established an equivalent perspective promoting a broad left-liberal alliance against fascism and in support of the labor movement, racial justice, and New Deal social democracy in the United States. ${ }^{35}$ Writers Take Sides was part of a wide- 
ranging international effort to mobilize prominent cultural figures in defense of the Spanish Republic. ${ }^{36}$ In addition to Steinbeck, contributors included Ernest Hemingway, Upton Sinclair, Thornton Wilder, and Richard Wright among other well-known writers, some of whom were tied to the Party and others merely supportive of the cause.

As already noted, Steinbeck's brief statement began by connecting European fascism to his domestic concerns. In line with his analysis of California, he presented the conflict in Spain as a matter of human freedom endangered by the interests of money: "Your question as to whether I am for Franco is rather insulting," he wrote. "Have you seen anyone not actuated by greed who was for Franco?" Fundamentally, Steinbeck's position defended the rights of less powerful individuals against the free rein of wealthy interests: "I am treasonable enough not to believe in the liberty of a man or group to exploit, torment, or slaughter other men or groups. I believe in the despotism of human life and happiness against the liberty of money and possessions." ${ }^{\text {37 }}$

The overlap with Steinbeck's understanding of American politics would continue in his 1942 novella The Moon Is Down. Although the economic aspects of fascism are given little explicit attention, the story returns to Steinbeck's familiar concern with the threat posed to human freedom by oppressive group forces. In this instance, Steinbeck conveys his confidence in the capacity of liberal society to resist an occupying army/phalanx. Set in an unnamed Scandinavian country and clearly reflecting the German occupation of Norway, the novella describes how the people of a coastal mining town fight back against a seemingly irresistible army that has taken control of the town and seized the coal mine. After a miner is executed for killing an officer of the occupying army, the townspeople respond with repeated acts of sabotage on the mining operation. Others escape to England and enlist military support, including the covert delivery of dynamite to aid the sabotage. The townspeople's personal conduct also isolates the soldiers, who "find themselves prisoners in the town they have conquered, oppressed by the unspoken hatred that surrounds them." ${ }^{38}$ The book ends with the impending execution of Mayor Orden, who has refused to collaborate with the commanding officer, Colonel Lanser, in trying to pacify the community. As the mayor speaks his final words, a nearby explosion makes clear that the resistance will continue, showing that a free people cannot be subdued.

The story's message was partly a matter of wartime propaganda. Steinbeck wrote the novella under the sponsorship of what later became the Office of Strategic Services, working as part of a unit known as the Foreign Information Service (FIS). The book was secretly published across Europe, and "virtually every occupied country had its own translation circulating by the time of the Allied landings in Normandy in June 1944." A play version was also staged in New York in 1942 and Sweden and England in $1943 .{ }^{39}$ But the deeper themes of the novella are not merely a matter of providing moral support and inspiration to the resistance movements in Europe. Instead, we can trace significant con- 
nections in The Moon Is Down to Steinbeck's previous analysis of fascism and the likely basis of opposition to such politics. Initially, in fact, Steinbeck had intended his work to be a play set in an American town, to show the possibility that such a thing "could happen here" (recalling Sinclair Lewis's 1935 novel It Can't Happen Here). Yet while this idea was rejected by the FIS, the thematic content of the novella reveals several important parallels with Steinbeck's farm labor novels. ${ }^{40}$

The phalanx analysis, although not applied in the consistent manner of In Dubious Battle, is again used to characterize mass mobilization. Most dramatically, at the end of the novel the mayor contrasts the indomitable spirit of the townspeople with the "herd men" of the occupying army: "Free men cannot start a war, but once it is started, they can fight on in defeat. Herd men, followers of a leader, cannot do that, and so it is always the herd men who win battles and the free men who win wars." ${ }^{" 11}$ Along the same lines, Orden's modest role as mayor is earlier contrasted with the power of an unnamed Leader who serves as the Hitler figure directing the obeying fascist army. When Colonel Lanser requires Orden to remain as mayor and prevent trouble among the townspeople, Orden explains that he does not know how the people will respond: "Sir, I am of this people, and yet I don't know what they will do.... Some people accept appointed leaders and obey them. But my people have elected me. They made me and they can unmake me. Perhaps they will if they think I have gone over to you. ${ }^{42}$ The distinction is between a community of individuals capable of independent action and a mob-like, militarized (fascist) culture associated with the unthinking and subservient men of the phalanx. Despite this contrast, Steinbeck was criticized at the time for being too sympathetic in his portrayal of Nazi occupation. Yet for Steinbeck, it was necessary to acknowledge the human qualities of characters like Colonel Lanser in order to show how the phalanx transforms individuals into group men with potentially repressive consequences. ${ }^{43}$

Less directly, Orden's last conversation with his friend, Dr. Winter, expresses a similar sentiment about the dangers of the mob. Quoting from Plato's Apology, Orden struggles to remember the wording of Socrates' assertion that "a man who is good for anything ought not to calculate the chance of living or dying; he ought only to consider whether he is doing right or wrong." ${ }^{\prime 4} \mathrm{He}$ then notes Socrates' prophesy to his judges, in which Socrates declares that "to you who are my murderers ... punishment far heavier than you have inflicted on me will surely await you. ... Me you have killed because you wanted to escape the accuser, and not to give an account of your lives," the quote continues, "but that will not be as you suppose. . . . For I say that there will be more accusers of you than there are now." ${ }^{45}$ Beyond alluding to the resistance of the townspeople, Orden is comparing his own moral virtue with the immorality of the herd that puts him to death. He has stayed true to his personal sense of justice, going to his death rather than degrading himself by pleading with (or furthering the interests of) the corrupt forces that condemn him. 
Without overstating Steinbeck's intention in drawing this parallel, it is worth recalling that the community against which Socrates defends himself is the democracy of Athens, which for Socrates amounted to a mob resentful of his attempts to rouse them to face their own ignorance. As Socrates explains, he is a gadfly performing a great service to the city: "if you kill me, you will not easily find such another man as I. . . . I rouse you. I persuade you. I upbraid you." But this antagonizes his fellow citizens: "Perhaps you are angry, as men roused from sleep are angry, and perhaps you will swat me, persuaded by Meletus that you may lightly kill. Then you will continue to sleep out your lives, unless the God sends someone else to look after you." "46 Innocent in relation to the charge of impiety, Socrates asserts that his real crime is to have aroused widespread enmity by his honesty, so that he confronts the "grudging slander of the multitude." "It has convicted many another good and decent man," he continues, "I think it will convict me." R. E. Allen's commentary underlines this point, concluding that "popular emotion, the grudging slander of the Many, represented in all its unreasoning intensity by Anytus, is not halted in its course by logic. Socrates went to his death on the basis of an undistributed middle. The gadfly was swatted. ${ }^{\prime 47}$ Despite the very different circumstances of The Moon Is Down, the reference to Socrates further conveys Steinbeck's sense of the danger posed to society by a mass politics of "herd men" driven by "popular emotion" and "unreasoning intensity" that threatens to overwhelm the higher human qualities.

If Steinbeck's response to fascism therefore entails a defense of liberal individualism against a degraded mass politics tied to business power, he nevertheless also looked to "the people" as a potential resource against the fascist threat. Here The Moon Is Down points back to the enthusiasm for the Okies in The Grapes of Wrath. Small town democracy defines Orden's self-understanding and gives him confidence in the people's ability to carry on their fight. When Lanser presses Orden to "co-operate for the good of all," Orden responds: "This is a little town. I don't know. The people are confused and so am I. ... When the town makes up its mind what it wants to do, I'll probably do that." "But you are the authority," says Lanser. "You won't believe this," Orden asserts, "but it is true: authority is in the town... This means we cannot act as quickly as you, but when a direction is set, we all act together." 48

The townspeople's ability to take the initiative and determine their own fate recalls the values Steinbeck associates with the Okies, who bring their older American traditions to California as an antidote to corporate capitalist farming. "Having been brought up in the prairies where industrialization never penetrated," Steinbeck writes, "they have jumped with no transition from the old agrarian, self-containing farm, where nearly everything used was raised or manufactured, to a system of agriculture so industrialized that the man who plants a crop does not often see, let alone harvest, the fruit of his planting, where the migrant has no contact with the growing cycle." Crucially, this background means they also remain democrats: "There is another difference between their 
[old] life and the new. They have come from little farm districts where democracy was not only possible, but inevitable, where popular government, whether practiced in the Grange, in church organization, or in local government, was the responsibility of every man." ${ }^{49}$ For Steinbeck the Okies thus embodied "the nation's much vaunted 'Jeffersonian' democratic culture" and the associated qualities of "initiative and self-reliance." ${ }^{50}$ It is for this reason that the migrants so readily adapt to the self-governance and collective responsibilities of life in the federal farm camps, exemplified by "Weedpatch" in The Grapes of Wrath. And this same capacity for democracy suggests the migrants' ability to participate in wider efforts to uphold the liberal American order, whether through New Deal coalition politics or labor struggle. ${ }^{51}$ "The new migrants to California from the dust bowl are here to stay," Steinbeck concluded; "they are of the best American stock, intelligent, resourceful, and, if given half a chance, socially responsible." 52

In an important sense, then, Steinbeck's optimism about popular resistance to fascism itself rests on a kind of traditionalism and faith in small town or agrarian people against the corrupting forces of modern corporatism in all its forms. Even as Steinbeck shows Tom Joad moving beyond his clan identity to a larger vision of common humanity and collective struggle for justice, the Emersonian aspects of Tom's emerging worldview (the "one great soul" or Oversoul) again convey a link to older American traditions, referencing the self-sufficiency and independence of mind so valued by Emerson..$^{53}$ Group mobilization is most likely to avoid the oppressive aspects of the phalanx analysis (and instead constitute a more positive phalanx) precisely when it springs from such roots. ${ }^{54}$ By contrast, a negative understanding of the collective capacities of modern, deracinated "industrial" workers comes through in the depiction of the atomized farm laborers of In Dubious Battle, who can only combine as an irrational and self-destructive phalanx.

Despite this anxiety, the populist dimensions of Steinbeck's writing, along with his own willingness to actively engage in related political efforts, brought him under the broad umbrella of the Popular Front. This is consistent with Denning's understanding of how the crisis of the 1930s led to the "laboring" of American political culture in the context of an "insurgent social movement forged from the labor militancy of the fledgling CIO, the anti-fascist solidarity with Spain, Ethiopia, China, and the refugees from Hitler, and the political struggles on the left of the New Deal. ${ }^{\prime 55}$ Yet in keeping with Rogin's criticism of Denning's perspective (and setting aside for the moment Denning's own views on Steinbeck), to simply position Steinbeck as an important part of a leftward cultural shift is to risk obscuring the political conflicts in this milieu, missing out on how Steinbeck anticipated central elements of the liberal anticommunism that escalated in the postwar period. The centrality of fascism to Steinbeck's political analysis in the late 1930s and early 1940s accordingly entailed a complex relationship with the Communist-aligned radical left. Having traced the underlying character of Steinbeck's views on fascism, we can con- 
clude by considering how this particular form of anti-fascism both defined his active involvement in the Popular Front and informed his concerns about the ramifications of radical left politics.

\section{Steinbeck and the Popular Front}

While obviously supportive of the New Deal labor movement, Steinbeck's fear of men in groups gave rise to a concern not just about fascism, but also about labor upheaval in response to fascism. This view of labor's phalanx possibilities set him apart from the Communist Party's version of labor radicalism and in turn colored his analysis of Communist organizing efforts. His account of the Party organizers in In Dubious Battle expressed skepticism about Communist political ends that led to the manipulation of the farm workers' phalanx impulses. As noted above, Steinbeck articulated similar concerns about communism (alongside fascism) in his contribution to Sea of Cortez in 1941, before adopting an increasingly anti-radical perspective in the postwar period. ${ }^{56}$ Nonetheless, fascism stood as the most immediate danger to American society, and the Popular Front conveyed a sense of urgency in responding to this crisis. Moreover, the Popular Front mobilization was itself a broad effort extending beyond the Communist Party and invoking sentimental appeals to earlier American traditions that ran parallel to Steinbeck's own perspective. Steinbeck was therefore able to engage with several Popular Front efforts specifically in line with the political concerns of his novels and journalism.

Steinbeck's personal connections to Communist labor organizers dated back to the early 1930s and the Cannery and Agricultural Workers' Industrial Union (CAWIU). Several of his friends were involved in actively supporting the union, notably including blacksmith and sculptor Francis Whitaker, who was a leader in the local John Reed Club (a national cultural organization sponsored by the Communists). Steinbeck's first wife, Carol, also facilitated his engagement with the Left through her own political concerns and interest in radical publications. This went so far as her decision to join the Communist Party in 1937, though perhaps largely with the intent of testing local reaction and provoking Steinbeck's family. ${ }^{57}$ Through Whitaker, Steinbeck met an important labor organizer, James Harkins, and also the writers Ella Winter and Lincoln Steffens, who fostered a radical and Communist Party-oriented political and cultural milieu around their home in Carmel. These ties also brought Steinbeck into contact with several CAWIU organizers who provided the strike accounts that became the basis for In Dubious Battle. ${ }^{58}$

Jackson Benson observes that Steinbeck was emotionally distant from the plight of the farmworkers and fascinated but put off by "the spirit of holy mission" exuded by the young Communist activists who frequently visited the Steinbeck cottage in Pacific Grove. ${ }^{59}$ Whitaker and Winter held similar views about Steinbeck's lack of political commitment at that time, noting respectively that he "was very naïve of politics" and that "he did not want to be connect- 
ed to any one side lest people thought he was writing propaganda." ${ }^{\prime 60}$ A letter Steinbeck wrote just after the publication of In Dubious Battle in early 1936 expressed his ambivalence about the Communists: "Dear Louis Paul: I don't like communists either, I mean I dislike them as people. I rather imagine the apostles had the same waspish qualities ... but ... some of these communist field workers are strong, pure, inhumanly virtuous men. Maybe that's another reason I personally dislike them and that does not redound to my credit." ${ }^{\prime 61}$ Yet if the Communists displayed the kind of dangerous intensity Steinbeck associated with the phalanx, the seriousness of their engagement with social issues in California nonetheless impressed him and shaped his own behavior. It was under the influence of Steffens and the young CAWIU organizers that Steinbeck had immersed himself in a close assessment of agricultural conditions in California. As Benson notes: "Over the next few years, he spent more time looking, and looking carefully, at the California farm-labor situation in its various aspects than anybody else, except, perhaps, for a handful of government and academic experts." ${ }^{62}$

Besides informing his novels, the resulting analysis of domestic and international fascism informed Steinbeck's participation in several Popular Front initiatives. In the United States, the Popular Front as advanced by the Communists (under the direction of the Comintern) eventually embraced an alliance between the pro-Communist left and New Deal Democrats on the grounds of a necessary defense against fascism. This was a sharp break with Third Period Communist politics up through 1934, when the reformist left and the emerging New Deal were characterized as "social-fascism" and the main threat to Communist advance. For the Party, this transformation created opportunities to work with a wide range of prominent cultural and intellectual figures who could participate in broad Popular Front organizations devoid of earlier Communist rhetoric. ${ }^{63}$ Steinbeck fit into this political milieu even as his personal correspondence and In Dubious Battle revealed concerns about communism. In 1936 he signed on with other well-known California writers as a sponsor of the Western Writers' Congress that met in San Francisco and was affiliated with the League of American Writers. That November he also contributed a short story, "Breakfast," to the Lincoln Steffens memorial issue of the Carmelbased Popular Front magazine Pacific Weekly. ${ }^{64}$ By then under the editorship of Ella Winter (Steffens's widow), Pacific Weekly "ran numerous articles about the threat of fascism in the state, nation, and world under such titles as 'Fascism at Our Fingertips,' 'Seeing America Fascist,' and 'Fascist Signs Everywhere."' 65 Steinbeck's story described a shared breakfast with two migrant workers who were enjoying a period of steady employment, an account that emerged from his visits "to the migrant camps in the Salinas area to listen to the workers talk" in preparation for In Dubious Battle. ${ }^{66}$

In 1938 Their Blood Is Strong was published by the Simon J. Lubin Society. The organization was started by Communist Party member and former Farm Security Administration (FSA) employee Helen Hosmer to aid farmwork- 
ers in California. It received the support of a number of prominent California leftists while exposing the activities of the Associated Farmers and providing information to the La Follette Committee during its investigations of vigilantism in California agriculture. ${ }^{67}$ That same year, Steinbeck's own Popular Front profile was further raised by the creation of the John Steinbeck Committee to Aid Agricultural Organization. Rick Wartzman notes that Steinbeck served "in the (largely ceremonial) role of state chairman," while others, including Carey McWilliams and actress and future congresswoman Helen Gahagan Douglas, handled the day-to-day work. The committee promoted the expansion of FSA camps and related policies to benefit migrant workers and in December was among the groups that worked with the FSA to put on a Christmas party at a federal farm labor camp in Shafter, California. Gahagan Douglas's husband, Melvyn Douglas, chaired the event, with a host of other Hollywood stars in attendance. Steinbeck also wrote about it for the People's World, one of several articles on farmworkers he contributed to the West Coast Communist newspaper in the late 1930s. ${ }^{68}$ Steinbeck's piece warned that one-time gifts of food and candy could generate hatred among the workers and simply "serve to emphasize the poverty of the recipients." The situation instead required an ongoing effort, sending the message that "we are working with you, not for you, to the end that the good life which is your right will not be longer withheld." ${ }^{\prime \prime 9}$

At the national level, Steinbeck became a member of the League of American Writers, including the National Executive Council, in 1937. The call for the Second American Writers' Congress that year was "dominated by the theme of fascism." By then the league had moved away from "the openly pro-Communist tone of the 1935 meeting," deemphasizing Communist participation and highlighting prominent supporters such as Ernest Hemmingway. ${ }^{70}$ Along with his contribution to Writers Take Sides, Steinbeck held the nominal role of League vice president from 1939 to 1940. His opposition to Franco also led him to send money for Republican ambulances in Spain. ${ }^{71}$

All of this activity caused the FBI to begin investigating Steinbeck in 1936, tracking his behavior and "accumulating material on him" in part provided by the Dies Committee on Un-American Activities. This ongoing investigation would later hold up Steinbeck's work with the FIS during the war. Steinbeck also wrote to Carlton Sheffield in 1939 that the Associated Farmers "have tried to make me retract things by very sly methods." In the face of this pressure, Steinbeck sent documentation on farmworker conditions to the La Follette Committee before its West Coast hearings. ${ }^{72}$ But he also became increasingly unhappy with the public attention that followed publication of The Grapes of Wrath. Political attacks on the novel were combined with personal abuse of Steinbeck, exacerbating existing strains in his personal life, including his collapsing marriage. According to Anne Loftis, "Steinbeck's general malaise heightened his anxiety about his political foes in California. . . . As the opposition to him grew in proportion to his fame, he debated strategies to meet it. Even 
before the publication of The Grapes of Wrath he became concerned about covering his tracks. He expressed fear of physical attack." 73

Steinbeck's anxieties about the charged response to The Grapes of Wrath were tied to his sense of the seriousness of fascist crisis in California. His preferred policy solutions were generally in line with New Deal reforms, and he urged the federal government to continue support for the FSA camps and to extend the La Follette hearings. ${ }^{74}$ Yet he also felt that a social revolution was underway in America, particularly evident in the impact of the Okies in California. "Their coming here now," Steinbeck observed, "is going to change things almost as much as did the coming of the first American settlers. . . These people have the same vitality ... and they know just what they want." 75 In this, the Okie migration was representative of a larger social upheaval in response to the growing concentration of wealth and political power. It was the urgency of this struggle that brought Steinbeck into contact with the Popular Front, but he was also keen to emphasize the deeper American roots of what he was describing in California, hoping in turn that this would fend off his fascist opponents. In a letter to his publisher, Pascal Covici, Steinbeck stressed the value of using the "Battle Hymn of the Republic" as the novel's endpapers: "The fascist crowd will try to sabotage this book because it is revolutionary. They will try to give it the communist angle. However, the Battle Hymn is American and intensely so.... So if both words and music are there the book is keyed into the American scene from the beginning. ${ }^{976}$ Just like his celebration of the Okies as the embodiment of American small town and agrarian democracy, the "Battle Hymn" signaled Steinbeck's view of the conflict in California as another moment in the struggle for freedom that characterized American history as he understood it.

For Steinbeck, this view of the Okies as an extension of earlier American experiences, including the American Revolution and western migration, may have distinguished his analysis from overly schematic radical views of social conflict that failed to understand specific national traditions. ${ }^{77}$ But, of course, this emphasis on American history was entirely consistent with Popular Front political culture, including that of the Communist Party. Part of the Communist effort to integrate into the New Deal mainstream and forge an anti-fascist coalition entailed highlighting the Party's American identity. Communism was characterized as "Twentieth Century Americanism," Washington, Lincoln, and Jefferson were claimed as ancestors in the struggle against big business tyranny, and "the 'Star-Spangled Banner' became the official hymn at Party meetings." 78 As Denning asserts, "there is no question that the politics and poetics of Americanism lay at the center of the Popular Front social movement." ${ }^{79}$ In this context, Steinbeck's work could be uncritically celebrated by Party cultural figures. Publications including the Daily Worker and New Masses heralded The Grapes of Wrath as a great work of proletarian fiction. ${ }^{80}$ Complicating this alignment, Denning argues that Steinbeck's celebration of the Okies involved a kind of racial populism counter to the "pan-ethnic Americanism" evident in many aspects of Popular Front culture (a contrast that comes through in the much greater 
attention given to Mexican and Asian immigrant farmworkers in California by Carey McWilliams). But there can be no doubt that Steinbeck's work was taken up in Popular Front circles as a powerful expression of the people's struggle against big business. ${ }^{81}$

Finally, Steinbeck's Popular Front affinities also emerge in the overlap between his work and that of Orson Welles, whom Denning describes as "the American Brecht, the single most important Popular Front artist in theater, radio, and film, both politically and aesthetically." Like Steinbeck, Welles's work was centrally concerned with fascism and the dangers of mass manipulation, including in the United States. This political orientation was evident in most of his Mercury Theatre productions and in key films, including Citizen Kane. For Welles, Denning argues, "the Popular Front was the anti-fascist alliance," and "most of his ... affiliations [were] with anti-fascist organizations." Fascist culture involved the threat of a "hypnotized mass public," against which radical artists must establish an alternative democratic culture. ${ }^{82}$ As Welles wrote, "fascism, we know, sells itself by making its appeal to the emotions rather than to reason, to the senses rather than to the mind. Showmanship is fundamental to the fascist strategy, and the chief fascist argument is the parade. ${ }^{183}$ The parallels with Steinbeck's understanding of mob thinking and emotional manipulation are clear. In the context of the growing crisis of fascism, Steinbeck's own appeals to earlier American values against corporate power and the dangers of mass irrationalism accordingly positioned him as an important cultural figure within the Popular Front and brought him into a sustained collaboration with Communists and Party sympathizers.

However, these very concerns also defined the boundary of Steinbeck's ties to the Communist-aligned left. Steinbeck could easily participate in Popular Front efforts as the movement intersected with his own response to what he saw as California fascism. Yet alongside this positive overlap, he also saw the Communists as the expression of another form of dangerous mass politics, and rejected their rigidity and party discipline. In a 1940 letter to his literary agent, Elizabeth Otis, Steinbeck wrote of "the party line left" that "I never went over to them - they shifted to me and then away." ${ }^{94}$ In fact, Steinbeck had moved to the left in terms of his openly partisan perspective and willingness to support antifascist causes. But this statement nonetheless reveals Steinbeck's own sense of how his relationship with the Communist left evolved. According to Benson, in the period of the Nazi-Soviet pact and the accompanying rapid changes in party views on Roosevelt and the war, Steinbeck joined others in Ed Ricketts's Cannery Row lab in baiting visiting Party members by pretending to be unaware of Communist shifts in policy. Steinbeck's contribution to support Finland against the Soviet invasion in 1939 also antagonized old friends like Ella Winter. ${ }^{85}$

Steinbeck's politics were thus ultimately indicative of the breadth of the Popular Front outside the Communist Party. He supported progressive reforms and identified with the plight of "the people" while maintaining his political independence, including skepticism in relation to the Communists with whom 
he worked. At times his sympathy for the Party's efforts was substantial, but there was also from the outset a consistent expression of concern over the mass repression he saw as a fundamental threat in communism. This distance from the "Party line left" also calls attention to underlying political strains within the Popular Front and the New Deal coalition that are sometimes overlooked in accounts that emphasize the varied political and cultural projects linked to this milieu. In some respects, Steinbeck's fears about communism even point to the liberal anti-communism that came to dominate after the war. If, as Steinbeck wrote in Sea of Cortez, the communist state would repress all rebels (just as fascism would repress the "strike-raddled businessman"), then a defense of individual freedom could be used to justify purging Communists and other radicals from the realm of legitimate politics, independent of their actual actions. This was indeed the justification for a demonizing form of postwar liberalism that repressed and criminalized the Communist Party. As Rogin emphasizes, "Truman and his anti-Communist, liberal supporters distinguished the Communist Party from legitimate political oppositions." ${ }^{86}$ In this regard, American pluralists were narrowing the scope of American political culture behind the claim of preserving it.

Yet if Steinbeck anticipates this trajectory of American liberalism in his analysis of fascism and communism as parallel forms of totalitarianism, he was also highly aware of the dangers of anti-communism and the ways that red baiting was being used by interests such as the Associated Farmers to discredit all critics. Such politics were effectively mocked in The Grapes of Wrath and elsewhere in Steinbeck's writing (and he retained this understanding of domestic anti-communism into the Cold War years). ${ }^{87}$ This again positioned him as an important voice in a Popular Front challenge to the restrictive political culture advanced by organized business interests. Faced with this right-wing repression, Steinbeck's anti-fascism provided the basis for a unified view of domestic and international politics that moved his liberalism to the left without surrendering his ties to a deeply felt individualism rooted in distinctly American traditions and myths.

\section{Notes}

1. John Steinbeck, "From Writers Take Sides," in John Steinbeck, America and Americans and Selected Nonfiction, ed. Susan Shillinglaw and Jackson J. Benson (New York: Viking, 2002), 88 .

2. For the background to Their Blood Is Strong, see A Companion to The Grapes of Wrath, ed. Warren French (New York: Viking Press, 1963), 51-53.

3. Their Blood Is Strong in A Companion to The Grapes of Wrath, 65-66, 87; February 1938 letter to Elizabeth Otis in Steinbeck: A Life in Letters, ed. Elaine Steinbeck and Robert Wallsten (New York: Viking Press, 1975), 157-59; on the terminology describing California agriculture from the 1930s forward, see Frank Bardacke, Trampling Out the Vintage: Cesar Chavez and the Two Souls of the United Farm Workers (New York: Verso, 2012), 32-33.

4. See, for example, Alexander Saxton, "In Dubious Battle: Looking Backward," Pacific Historical Review 73 (May 2004); David Wyatt, "Introduction," in New Essays on the Grapes of Wrath, ed. David Wyatt (Cambridge: Cambridge University Press, 1990); Morris Dickstein, "Steinbeck and the Great Depression," South Atlantic Quarterly 103 (winter 2004); Alan Wald, "Steinbeck and the Proletarian Novel," in Cambridge History of the American Novel, ed. Leonard 
Cassuto, Clare Virginia Eby, and Benjamin Reiss (New York: Cambridge University Press, 2011), $671-85$

5. Peter Buitenhuis, "Prelude to War: The Interventionist Propaganda of Archibald MacLeish, Robert E. Sherwood, and John Steinbeck," Canadian Review of American Studies 26 (winter 1996): 22; See also Roy Simmonds, John Steinbeck: The War Years, 1939-1945 (Lewisburg, PA: Bucknell University Press, 1996), which notes the analogies Steinbeck made between the farm workers' plight and that of the European refugees created by fascism (pp. 32-33) but does not explicitly consider Steinbeck's analysis of fascism in America.

6. Michael Denning, The Cultural Front: The Laboring of American Culture in the Twentieth Century (New York: Verso, 1996), xviii. For Denning's further elaboration on anti-fascism and the Popular Front, including a view of Steinbeck's work as outside the Popular Front framework because of its racial populism and sentimental politics, see The Cultural Front; 11, 267-68; on antifascism and the Popular Front in the United States, see also Alan M. Wald, Trinity of Passion: The Literary Left and the Anti-fascist Crusade (Chapel Hill: University of North Carolina Press, 2007); Daniel Geary, "Carey McWilliams and Anti-fascism, 1934-1943," Journal of American History 90 (December 2003).

7. For a discussion of the transformations of American liberalism in the New Deal era see Alan Brinkley, The End of Reform: New Deal Liberalism in Recession and War (New York: Vintage Books, 1995), 8-11.

8. Denning, Cultural Front, 4-6, 21-26.

9. Michael Rogin, review of The Cultural Front, Journal of American History 84 (September 1997), $712-13$.

10. June 21, 1933, letter to Carlton Sheffield in Steinbeck: A Life in Letters, 74-77.

11. For a parallel discussion of the phalanx theory and mass politics that focuses on Steinbeck's understanding of labor struggles in the 1930s, see Charles Williams, "Group Man and the Limits of Working-Class Politics: The Political Vision of Steinbeck's In Dubious Battle," in A Political Companion to John Steinbeck, ed. Cyrus Ernesto Zirakzadeh and Simon Stow (Lexington: University Press of Kentucky, 2013), 119-45.

12. Undated 1933 letter to George Albee in Steinbeck: A Life in Letters, 80.

13. June 21, 1933, letter to Sheffield in ibid., 76.

14. Undated 1933 letter to George Albee in ibid., 80; and see Jackson J. Benson, The True Adventures of John Steinbeck, Writer (New York: Viking Press, 1984), 269-70.

15. Benson, True Adventures of John Steinbeck, 269, 719-20.

16. Geary, "Carey McWilliams and Anti-fascism," 912-13.

17. John Steinbeck, In Dubious Battle (New York: Penguin Books, 1979), 28.

18. Ibid., 152.

19. Ibid., 150 .

20. January 15, 1935, letter to George Albee in Steinbeck: A Life in Letters, 98-99.

21. For a longer analysis of the political implications of the phalanx analysis of In Dubious Battle, see Williams, "Group Man and the Limits of Working-Class Politics."

22. Steinbeck, Their Blood Is Strong, 65-69, 87.

23. Ibid., 68-69, 87.

24. John Steinbeck and Edward F. Ricketts, Sea of Cortez: A Leisurely Journal of Travel and Research (New York: Viking Press, 1941), 258-59.

25. Daniel Guerin, Fascism and Big Business (New York: Pioneer Publishers, 1939), 54-56.

26. Dwight Macdonald, "Germany - Capitalism or Bureaucratic Collectivism?" New International 7 (February 1941); Dwight Macdonald, "Fascism-A New Social Order," New International 7 (May 1941). Macdonald's views drew from the dissenting Trotskyism of Max Shachtman (and the ideas of Shachtman's former ally James Burnham) that characterized Russia as bureaucratic collectivist but faulted Shachtman for not reaching the same conclusion about fascist Germany. On Shachtman and Burnham, see Peter Drucker, Max Shachtman and His Left: A Socialist's Odyssey through the "American Century" (Atlantic Highlands, NJ: Humanities Press, 1994).

27. On Macdonald's own evolving fears of mass society and emphasis on individualism, see Michael Wreszin, A Rebel in Defense of Tradition: The Life and Politics of Dwight Macdonald (New York: Basic Books, 1994).

28. See, for example, Peter Drucker, Max Shachtman and His Left; Alan M. Wald, The New York Intellectuals: The Rise and Decline of the Anti-Stalinist Left from the 1930s to the 1980s (Chapel Hill: University of North Carolina Press, 1987).

29. John Steinbeck, The Grapes of Wrath (New York, Penguin Books, 1992), 43-44.

30. Ibid., 385 .

31. Ibid., 388 .

32. Ibid., 386 .

33. On the New Deal liberal concern to balance corporate power with other interest groups in pursuit of a pluralistic democratic capitalism, see William E. Leuchtenberg, Franklin D. Roosevelt and the New Deal: 1932-1940 (New York: Harper and Row, 1963); Nelson Lichtenstein, State of the Union: A Century of American Labor (Princeton: Princeton University Press, 2002); Eric 


\section{Charles Williams}

Rauchway, The Great Depression and the New Deal: A Very Short Introduction (New York: Oxford University Press, 2008).

34. Steinbeck, Their Blood Is Strong, 87.

35. Harvey Klehr, The Heyday of American Communism: The Depression Decade (New York: Basic Books, 1984), 352-56; Franklin Folsom, Days of Anger, Days of Hope: A Memoir of the League of American Writers, 1937-1942 (Niwot: University Press of Colorado, 1994); on the key political positions of the Popular Front and its cultural manifestations, see Denning, Cultural Front, 10-14, 125.

36. On the League of American Writers and the more general range of Communist-led cultural mobilizations in support of Spain, see Denning, Cultural Front, 224-25, 326, 332; Franklin Folsom, Days of Anger, Days of Hope,30-32; Harvey Klehr, Heyday of American Communism, 354-55; Irving Howe and Lewis Coser, The American Communist Party: A Critical History (1957; reprint, New York: Frederick A. Praeger, 1962), 313; and in the European context see Robert Thornberry, "Writers Take Sides, Stalinists Take Control: The Second International Congress for the Defense of Culture (Spain 1937)," Historian 62 (spring 2000): 589-606.

37. Steinbeck, "From Writers Take Sides," 88.

38. Simmonds, John Steinbeck: The War Years, 99.

39. Ibid., 117-21, 167, 170-71; on Steinbeck's work for the FIS, see ibid., 93-94; Benson, True Adventures of John Steinbeck, 487-88.

40. Benson, True Adventures of John Steinbeck, 488, 491.

41. John Steinbeck, The Moon Is Down (Viking Press, 1942), 185-86.

42. Ibid., 36.

43. On this point see Joseph Fontenrose, John Steinbeck: An Introduction and Interpretation (New York: Barnes and Noble, 1963), 100; on the reception of The Moon Is Down, see Peter Lisca, The Wide World of John Steinbeck (New Brunswick, NJ: Rutgers University Press, 1958), 186-88.

44. Steinbeck, The Moon Is Down, 178.

45. Ibid., 181-82.

46. The Dialogues of Plato, Volume I, translated and with analysis by R. E. Allen (New Haven, CT: Yale University Press, 1984), 30e-31a (pp. 93-94).

47. Ibid., 76.

48. Steinbeck, The Moon Is Down, 40-41.

49. Steinbeck, Their Blood Is Strong, 57.

50. Cyrus Ernesto Zirakzadeh, "Revolutionary Conservative, Conservative Revolutionary? John Steinbeck and The Grapes of Wrath," in A Political Companion to John Steinbeck, 34; see also the classic essay by Chester E. Eisinger, "Jeffersonian Agrianism in The Grapes of Wrath," University of Kansas City Review 14 (winter 1947), 149-54.

51. Williams, "Group Man and the Limits of Working-Class Politics," 136-38.

52. Steinbeck, Their Blood Is Strong, 87.

53. Yehoshua Arieli, Individualism and Nationalism in American Ideology (Cambridge, MA: Harvard University Press, 1964), 277-89.

54. On the possibility of a constructive form of phalanx within Steinbeck's analysis, see Richard Astro, John Steinbeck and Edward F. Ricketts: The Shaping of a Novelist (Minneapolis: University of Minnesota Press, 1973).

55. Denning, Cultural Front, 4.

56. Steinbeck and Ricketts, Sea of Cortez, 258-59; for an analysis that contrasts Steinbeck's later anti-radicalism to his radical sympathies in the 1930 s, see Wald, "Steinbeck and the proletarian novel," 674.

57. Simmonds, John Steinbeck: The War Years, 182; Robert DeMott, "Introduction" in The Grapes of Wrath (Penguin edition, 1992), xvii; Susan Shillinglaw, Carol and John Steinbeck: Portrait of a Marriage (Reno: University of Nevada Press, 2013), 140-44.

58. Jackson J. Benson and Anne Loftis, "John Steinbeck and Farm Labor Unionization: The Background of In Dubious Battle," American Literature 52 (May 1980): 219-20; Benson, True Adventures of John Steinbeck, 224-25, 293-309.

59. Benson, True Adventures of John Steinbeck, 294-96.

60. Quoted in Rick Wartzman, Obscene in the Extreme: The Burning and Banning of John Steinbeck's The Grapes of Wrath (New York: PublicAffairs, 2008), 76.

61. Benson, True Adventures of John Steinbeck, 294; February 1936 letter to Louis Paul in Steinbeck: A Life in Letters, 120.

62. Benson, True Adventures of John Steinbeck, 294.

63. Klehr, Heyday of American Communism, 15-17, 167-214, 349-64.

64. Anne Loftis, Witnesses to the Struggle: Imaging the 1930s California Labor Movement (Reno: University of Nevada Press, 1998), 172; Folsom, Days of Anger, Days of Rage, 323; Geary, "Carey McWilliams and Anti-fascism," 917.

65. Geary, "Carey McWilliams and Anti-fascism," 917.

66. Benson, True Adventures of John Steinbeck, 291, 298; John Steinbeck, "Breakfast," Pacific Weekly, November 9, 1936, 300. 
67. Wartzman, Obscene in the Extreme, 95-97; Loftis, Witness to the Struggle, 43-44, 172, 177; "Helen Hosmer: A Radical Critic of California Agribusiness in the 1930s," oral history interview by Randall Jarrell, McHenry Library, University of California, Santa Cruz (available at http:// digitalcollections.ucsc.edu/cdm/ref/collection/p265101 coll13/id/3564), 51-53, 74-75.

68. Wartzman, Obscene in the Extreme, 97-98; for further detail on the Steinbeck Committee see James R. Swensen, "Focusing on the Migrant: The Contextualization of Dorothea Lange's Photographs of the John Steinbeck Committee," in A Political Companion to John Steinbeck, 191-226.

69. Quoted in Wartzman, Obscene in the Extreme, 98.

70. Klehr, Heyday of American Communism, 354. 434.

71. Folsom, Days of Anger, Days of Hope, 323; Benson, True Adventures of John Steinbeck,

72. June 23, 1939, letter to Carlton Sheffield in Steinbeck: A Life in Letters, 187; Loftis, Witnesses to the Struggle, 172; Simmonds, Steinbeck: The War Years, 121.

73. Loftis, Witnesses to the Struggle, 171-72; see also Benson, True Adventures of John Steinbeck, 418-26.

74. Cliff Lewis, "Art for Politics: John Steinbeck and FDR," in After The Grapes of Wrath: Essays on John Steinbeck in Honor of Tetsumaro Hayashi, ed. Donald V. Coers et al. (Athens: Ohio University Press, 1995), 23-24.

75. Benson, True Adventures of John Steinbeck, 387

76. Quoted in ibid., 387.

77. Benson, True Adventures, 386-88.

78. Howe and Coser, The American Communist Party, 339; see also Klehr, Heyday of American Communism.

79. Denning, Cultural Front, 129.

80. Alan Wald, "Steinbeck and the Proletarian Novel," 671.

81. Denning, Cultural Front, 130, 267; Carey McWilliams, Factories in the Field: The Story of Migratory Farm Labor in California (Boston: Little, Brown, 1939); on Steinbeck's racial populism see also Kevin Hearle, "These Are American People: The Spectre of Eugenics in Their Blood Is Strong and The Grapes of Wrath," in Beyond Boundaries: Rereading John Steinbeck, ed. Susan Shillinglaw and Kevin Hearle (Tuscaloosa: University of Alabama Press, 2002), 243-24.

82. Denning, Cultural Front, 362, 365, 374; and see 362-402.

83. Quoted in ibid., 365.

84. October 5, 1940, letter to Elizabeth Otis quoted in Loftis, Witnesses to the Struggle, 219 footnote 37 .

85. Benson, True Adventures, 434; Loftis, Witnesses to the Struggle, 172.

86. Michael Rogin, Ronald Reagan, the Movie and Other Episodes in Political Demonology (Berkeley: University of California Press, 1987), 72, 280; see also Ellen Schrecker, "McCarthyism and the Decline of American Communism, 1945-1960," in New Studies in the Politics and Culture of U.S. Communism, ed. Michael Brown et al. (New York: Monthly Review Press, 1993); Melvyn P. Leffler, The Specter of Communism: The United States and the Origins of the Cold War, 1917-1953 (New York: Hill and Wang, 1994).

87. See, for example, Steinbeck, Their Blood Is Strong, 88-89; and on the postwar period, the discussion in Benson, True Adventures, 744-45. 